\title{
Dust in the Housing of Laying Hens: A case study
}

EAuthor(s)

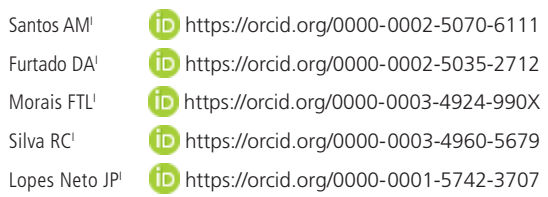

Agricultural Engineering at the Federal University of Campina Grande, Paraíba, Brazilm.

\section{-Mail Address}

Corresponding author e-mail address Adriana Maria dos Santos

Rua Alencar Pires de Almeida, 07, centro, Água Branca, Paraíba - CEP: 58748-000 -

Brasil.

Phone: +55 83996235921

Email: ttstadriana@gmail.com

\section{EKeywords}

Animal production, chemical risk, bioaerosols.

\section{ABSTRACT}

As dust particles in laying poultry houses can have negative effects on health and on the environment, this study aimed to measure and compare dust concentrations in egg production sheds. The experiment was carried out in three sheds: Californian shed (G1), conventional closed shed with artificial ventilation (G2) and conventional closed shed without artificial ventilation (G3), and the birds housed were in the 22nd week of housing, in Cuité, Paraíba, Brazil. The dust particles were collected by a gravimetric pump, attached to the workers' clothes, at the height of the respiratory zone, being removed at the end of the working day. Using the evaluation methodologies (total or breathable dust) according to NIOSH (1998), weighing was performed with sample concentration calculation, then the particle size was measured by microscopy according to the methodology described by Feret (Santos, 2001), with diameter of function obtained using an optical microscope, and particles classified by size (inhalable $<100 \mu \mathrm{m}$, thoracic $<25 \mu \mathrm{m}$ and breathable $<10 \mu \mathrm{m})$. Considering the limit of concentration $x$ exposure time of $3.0 \mathrm{mg} / \mathrm{m}^{3}$, according to ACGIH (2013), the sheds had the following values: G1-0.98 mg/m3 , G2-1.45 mg/m $/ \mathrm{m}^{3}$ and G3-1.13 mg/m In the classification of particles by size, the highest frequencies were $83 \%$ thoracic, $13 \%$ inhalable, and $4 \%$ breathable. With the results presented, the implementation of the Respiratory Protection Program - PPR is suggested.

\section{INTRODUCTION}

In meat and laying poultry production systems, air quality can be affected by high dust concentrations (Le Bouquin, 2019), which can cause health problems in employees and animals (Al Cambra-Lopez, 2011). Diseases induced by inhalation of different bioaerosols are related not only to their biological properties and chemical composition, but also to the number of inhaled particles and the place where they are deposited in the respiratory system.

$\mathrm{NIOSH}$ (1998) determines the classification of dimensions by size (inhalable $<100 \mathrm{um}$, thoracic $<25 \mathrm{um}$ and breathable $<10 \mathrm{um}$ ) and as assessment methods (total or breathable dust).

In this context, the study aims to measure and compare dust concentrations in egg production sheds.

\section{MATERIAL AND METHODS}

The study was carried out in poultry production units (eggs), and the sheds are located in Cuité - Paraíba, Brazil, at 06² 29 '01 "S latitude and $36^{\circ} 09$ ' $13^{\prime \prime} \mathrm{W}$ longitude. The experiment was carried out in the production phase, in different types of sheds: Californian shed (G1), conventional closed shed with artificial ventilation (G2) and conventional 
closed shed without artificial ventilation (G3), and the birds housed were in the 22nd week of housing.

The collection of breathable dust was carried out during 1 day of production and repeated in the three sheds, totaling one sample for each shed. The methodology used was defined by NIOSH (Osha, 1994), using the BDX-II sampling pump (brand: Sensidyne), calibrated for air flow rate of $1.7 \mathrm{~L} \mathrm{~min}-$ 1 with acceptable variation of $5 \%$, coupled to the breathable dust cyclone with cassette, containing a $5 \mu \mathrm{m}$ PVC (polyvinyl chloride polymer) membrane filter with a diameter of $37 \mathrm{~mm}$, previously sterilized. The device was attached to the worker's clothing at the height of the respiratory zone and removed at the end of the workday.

Study of collected material:

1- Weighing membrane filters before and after collection.

2- Image recording on the glass slide, with Olympus BX51 optical microscope - 5x optical magnification.

3- Size study, with Olympus Imaging Solution software, where the equivalent diameter is given by the length of any linear intersection, evaluating the distance between two lines tangent to the particle's projection, in a pre-fixed direction (horizontal and vertical). The method used to measure the particle size by microscopy was the diameter of the functions, which determines the distance between two tangent lines and the design of verification in the horizontal and vertical bars, providing information about size, shape and color, called the FERET method (Santos, 2001).

4- To express the results, the calculation of the sample concentration was performed based on ACGIH - American Conference of Governmental Industrial Hygienists (1998), according to the instructions and expression of $\mathrm{NHO}-08$ for the collection of solid particulate material suspended in the work environment (Fundacentro, 2009).

\section{RESULTS AND DISCUSSION}

In the collection carried out in the 3 sheds, the largest amount of dust was found in G2, so it is possible to infer that the use of artificial ventilation and the increase in air speed help to remove dust from the environment, whereas $\mathrm{G} 1$ had the lowest amount. This shed has side openings that increase the air flow and take the dust to the external environment; another difference is the number of hens housed and the, height of the cages $(1.30 \mathrm{~m})$, whereas in $\mathrm{G} 2$ and $\mathrm{G} 3$, the height of the cages reaches more than $3.0 \mathrm{~m}$, and the amount of dust released in the galleries is over the respiratory zone.

Table 1 - Dust collected by shed.

\begin{tabular}{lcc}
\hline Collection location & Weight/day $(\mathrm{mg})$ & Sample concentration $\left(\mathrm{mg} / \mathrm{m}^{3}\right)$ \\
\hline G1 & $0.80 \mathrm{mg}$ & $0.98 \mathrm{mg} / \mathrm{m}^{3}$ \\
G2 & $1.19 \mathrm{mg}$ & $1.45 \mathrm{mg} / \mathrm{m}^{3}$ \\
G3 & $0.93 \mathrm{mg}$ & $1.13 \mathrm{mg} / \mathrm{m}^{3}$ \\
\hline
\end{tabular}

Source: Author, 2020.

Considering the LEO - Occupational Exposure Limit, the maximum concentration is related to the nature and time of exposure to the product, which will not cause damage to the health of the worker during his working life under the condition of 8 hours of daily exposure. It is noted in the results of the evaluations that the tolerance limits stipulated by ACGIH (2013) in both jobs were not exceeded.

According to the classification of particles by size (inhalable $<100 \mu \mathrm{m}$, thoracic $<25 \mu \mathrm{m}$ and breathable $<10 \mu \mathrm{m})$ of $\mathrm{NIOSH}(1998)$, the results found in the present study were 13\% inhalable, $83 \%$ thoracic and $4 \%$ breathable. These particles can easily penetrate the respiratory system and transport microorganisms and fragments related to activities in the environment, such as food scraps, feathers and animal skins.

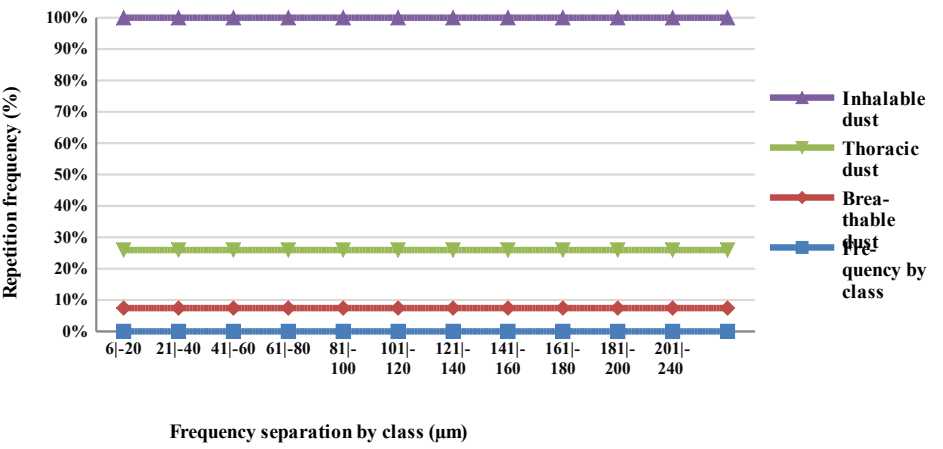

Figure 1 - Particle size for the samples collected (inhalable, thoracic and breathable). Source: Author, 2020.

Even with fractions above $100 \mu \mathrm{m}$, in $17 \%$, the existence of smaller dust particles cannot be ruled out (Figure 1). In terms of occupational health, ultra-fine particles may be more toxic than larger particles due to their aspects of deposition and disposition in the worker's body, but particles with the largest surface area by mass can act as a catalyst for reactions and their increased surface area could act as a transporter for microorganisms.

Takai et al. (1999), in closed and controlled environment sheds, for laying hens, found that the concentration of inhaled dust, fraction $<100 \mu \mathrm{m}$ of total dust, varied from $3.83 \mu \mathrm{m}$ to $10.4 \mu \mathrm{m}$ and with the means of dust inactivation around $3.60 \mu \mathrm{m}$. 
Santos AM, Furtado DA, Morais FTL, Silva RC, Lopes Neto JP
Dust in the Housing of Laying Hens: A case study

Brasil. Ministério da Economia. NR 9: programa de prevenção de riscos ambientais. Brasília; 2015. 7 p. [cited 2020 Apr 23]. Available from: https://enit.trabalho.gov.br/portal/images/ Arquivos_SST/SST_NR/NR09-atualizada-2019.pdf>.

Cambra-Lopez MT, Hermosilla, HTL, Lai AJA, Aarnink NWM. Source identification and quantification of particulate matter emitted from livestock houses. Transactions of ASABE 54:629-642; 2011.

Fundacentro. Coleta de material particulado. Sólido suspenso no ar de ambientes de trabalho [procedimento técnico]. São Paulo: Fundacentro; 2009.

Le Bouquin S, Huneau-Salaun A, Huonnic D, Balaine L, Martin S, Michel $\mathrm{V}$. Aerial dust concentration in cage-housed, floor-housed, and aviary facilities for laying hens. Poultry Science Association 2019;1:2827 $-2833$.

NIOSH - National Institute for Occupational Safety and Health. Particulates not otherwise regulated, total. Method 0500. In: Schelech PC, O'Connor PF, editors. NIOSH manual of analytical methods (NMAMß) [Publication 94-113]. $4^{\text {th }}$ rev. ed. Cincinnati: DHHS NIOSH; 1994. [cited 2020 Apr 23]. Available from: http://www.cdc.gov/niosh/docs/2003154/pdfs/0500.pdf.

NIOSH - National Institute for Occupational Safety and Health. Particulates not otherwise regulated, respirable. Method 0600. In: Schelech PC, $\mathrm{O}^{\prime}$ Connor PF, editors. NIOSH manual of analytical methods (NMAM®) [publication n. 94-113]. $4^{\text {th }}$ ed., Cincinnati: DHHS NIOSH; 1998. [cited 2020 Apr 23]. Available from: http://www.cdc.gov/niosh/docs/2003154/pdfs/0600.pdf.

Santos, AM . O tamanho das partículas de poeira suspensas no ar dos ambientes de trabalho. São Paulo: Fundacentro; 2001.

Takai H, Seedorf J, Pedersen, S. Dust and endotoxin concentrations in livestock buildings in norther Europe. Proceedings of the International Symposium On Dust Control In Animal Production Facilities, 1; 1999. Aarhus: Danish Institute of Agricultural Sciences; 1999. p.140-153. 
